\title{
Pelatihan Pembuatan Hand Sanitizer Alami dari Daun Sirih
}

\author{
Devi Anugrah1, Husnin Nahry Yarza*2, Rosi Feirina Ritonga ${ }^{3}$ \\ 1,2,3Program Studi Pendidikan Biologi, Fakultas Keguruan dan Ilmu Pendidikan, Universitas \\ Muhamamdiyah Prof. Dr. Hamka \\ *e-mail: husnin.rahry@uhamka.ac.id ${ }^{2}$
}

\begin{abstract}
This community service is a follow up of the research. The purpose of this service is to provide education about the Coronavirus or known as Covid 19. Education about this virus is important because there are still many people who do not really know the virus about how to avoid it to overcome it. In addition, training is also given to make natural hand sanitizers from betel leaves, making hand sanitizers is done in line with the high price of factory-made hand sanitizers whose prices are soaring amid covid pandemic 19, besides it can cause side effects if used excessively while hand sanitizers from betel leaves this is natural and safer to use. This community service can make people more aware of cleanliness and protect themselves and their families from viruses and disease threats.
\end{abstract}

Keywords: hand sanitizer, hygiene, Piper betle, literation,

\begin{abstract}
Abstrak
Pengabdian masyarakat ini merupakan tindak lanjut dari penelitian. Tujuan dilakukannya pengabdian ini adalah memberikan edukasi mengenai virus corona 19 atau dikenal dengan nama covid 19, edukasi mengenai virus ini penting karena masih banyak masyarakat yang belum begitu mengetahui virus tersebut tentang bagaimana menghindarinya hingga penanggulangannya. Selain itu juga diberikan pelatihan untuk membuat hand sanitizer alami dari saun sirih, pembuatan hand sanitizer ini dilakukan seiring mahalnya harga hand sanitizer buatan pabrik yang harganya melonjak ditengah pandemic covid 19, selain itu dapat menimbulkan efek samping jika digunakan secara berlebihan sedangkan hand sanitizer dari daun sirih ini bersifat alami dan lebih aman digunakan. Dengan adanya pengabdian masyarakat ini dapat membuat masyarakat lebih sadar akan kebersihan dan lebih menjaga diri dan keluarga dar virus dan ancaman penyakit.
\end{abstract}

Kata kunci: pembersih tangan, kebersihan, sirih, literasi

\section{PENDAHULUAN}

COVID-19 merupakan Coronavirus keluarga besar virus yang menyebabkan penyakit ringan sampai berat, seperti common cold, atau pilek dan penyakit serius seperti MERS dan SARS. Tanda-tanda virus ini adalah gejalanya demam dengan suhu di atas $38^{\circ} \mathrm{C}$, batuk, sesak napas yang membutuhkan perawatan di RS. Gejala ini menambah berat jika terjadi pada penderita dengan lanjut usia dan mempunyai penyakit penyerta lainnya seperti penyakit diabetes, jantung dan hipertensi. Di Indonesia khususnya dan di dunia COVID-19 ini sedang mengalami wabah pandemik.

Banyak cara yang dapat ditempuh untuk dapat mengurangi penularan virus ini diantaranya adalah dengan rajin mencuci tangan dengan sabun ataupun dengan menggunakan hand sanitizer yang menggunakan alcohol; mengurangi kontak dengan orang lain; menghindari kontak dengan orang sakit; jika mengalami gejala demam dan gangguan pernafasan menghindari keluar rumah kecuali untuk berobat, gunakan masker dan menerapkan etika bersin/ batuk. Tidak melakukan perjalanan jika keperluan tidak mendesak dan darurat.

Berdasarkan hal ini maka penulis tertarik untuk melakukan pelatihan pembuatan hand sanitizer bagi warga Aisyiyah Muhammadiyah Cileungsi. Hand sanitizer adalah gen ataupun cairan sebagai media pembersih tangan untuk menggantikan sabun dan air agar lebih praktis. Pemakaiannnya dirasakan efektif dan efisien dalam melawan virus. Keuntungan pemakaian hand sanitizer ini adalah dapat membunuh kuman, virus dan mikroorganisme dalam waktu yang lebih 
cepat. Jika air tidak ada maka hand sanitizer dapat menjadi salah satu solusi untuk membersihkan tangan kita (Fatimah, 2018).

Sirih merupakan salah satu tanaman obat yaitu 36 jenis dari 26 famili yang biasa dimanfaatkan oleh warga sekitar Muhammadiyah cabang Cileungsi ini (Yarza, 2019). Menurut Sari (2006) sediaan gel dari ekstrak daun sirih dengan kadar mulai 15\% mempunyai kemampuan menurunkan mikroorganisme di telapak tangan sampai 57\% dan ekstrak 25\% mampu menghilangkan semua mikroorganisme. Berdasarkan hal ini lah penulis menjadi tertarik untuk mengadakan pelatihan menggunakan hand sanitizer berbahan dasar sirih.

\section{METODE}

Edukasi tentang covid 19 dan pembuatan hand sanitizer alami dari daun sirih menjadi solusi yang ditawarkan tim pengabdian UHAMKA untuk mengatasi permasalahan mitra. Dengan adanya edukasi ini, maka pengetahuan mitra menjadi bertambah tentang Covid 19, dimana Covid 19 ini merupakan virus yang berbahaya dan mudah menular. Penularan dapat terjadi melalui kontak langsung ataupun media-media lainnya dari penyebaran virus tersebut misalnya, plastic, kardus, besi dan benda-benda lain yang biasa dipegang oleh orang. Edukasi mengenai covid 19 ini disampaikan langsung oleh tim yang dipaparkan oleh Bu Rosi.

Edukasi selanjutnya yaitu pembuatan hand sanitizer alami dari daun sirih, hand sanitizer ini berbahan alami dan tidak menimbulkan efek samping yang berbahaya jika sering digunakan, karena dimasa pandemic covid 19 ini kita harus menjaga kebersihan diri, harus sering mencuci tangan, menjaga jarak dan jika memungkinkan tetap dirumah saja. Edukasi pembuatan hand sanitizer alami dari daun sirih dilakukan praktik langsung.

Cara pembuatan hand sanitizer dari daun sirih ini yaitu; mengambil daun sirih kurang lebih sebanyak 7 lembar; kemudian panaskan dengan air $240 \mathrm{ml}$ hingga airnya sisa setengahnya, dinginkan, dapat tuangkan pada botol spray dan hand sanitizer siap digunakan. Prosedur pembuatan hand sanitizer dari daun sirih ini harus dilakukan secara aseptic dan sesuai dengan protocol Kesehatan. Agar hand sanitizer ini dapat digunakan secara aman dan sesuai dengan protocol Kesehatan.

\section{HASIL DAN PEMBAHASAN}

Pentingnya pengetahuan mengenai covid 19 dan hal apa saja yang diperlukan untuk malakukan pencegahannya merupakan langkah awal untuk menghindari covid 19 itu sendiri. Sebelum melakasanakan kegiatan, tim terlebih dahulu melakukan koordinasi dengan ketua Aisiyah Cileungsi untuk menentuka tempat dan waktu kegiatan selama beberapa kali, koordinasi ini selanjutnya dilanjutkan melalui chat dimedia social whatsapp dan telah disepakati waktunya dilaksanakan pada Kamis, 16 April 2020 di kantor cabang muhammadiyah Cileungsi. Selanjutnya, Tim melakukan finalisasi rancangan kegiatan. Mulai dari kesiapan agenda acara, narasumber, fasilitator, peserta, alat dan bahan praktek yaitu, beberapa lembar daun sirih, kompor, panci, pengaduk, dan botol spray, ketersediaan proyektor serta tempat yang disediakan oleh pihak Mitra. Pelaksanaan kegiatan pengabdian berupa edukasi, dengan catatan kegiatan tidak boleh dihadiri lebih dari 10 orang, setiap orang ini menjadi agent yang nantinya harus menyampaikan hasil diskusi ke warga lainnya, peraturan berikutnya setiap orang juga harus menjaga jarak dan wajib menggunakan masker sesuai dengan protocol kesehatan selama masa pandemik. 


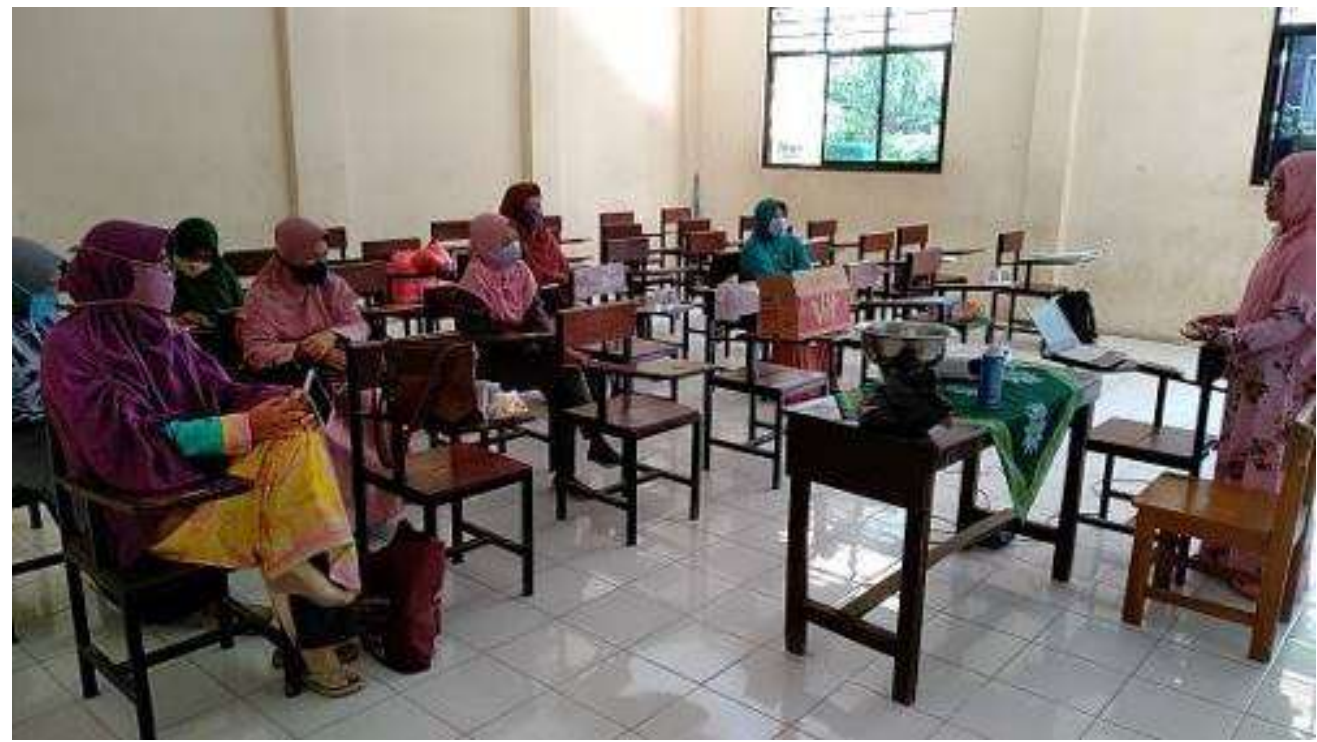

Gambar 1. Bu Rosi, sedang membuka acara

Pemaparan edukasi covid 19 dan pembuatan hand sanitizer alami dari daun sirih ini dilakukan oleh tim, pemaparan pertama oleh Bu Rosi memberikan penjelasan mengenai covid 19, penjelasan dimulai dari mana virus itu berasal, komponen yang menyusun tubuh virus itu sendiri, bagaimana penyebarannya hingga bagaimana cara pencegahan agar tidak terjangkit virus tersebut. Edukasi selanjutnya adalah membuat hand sanitizer yang berbahan daun sirih oleh Pak Devi, pembuatan dimulai dari menyiapkan daun sirih, kompor, panci, pengaduk, air, dan botol spray. Langkah pertama adalah memcuci daun sirih sebanyak tujuh lembar, kemudian mencacahnya, selanjutnya daun sirih direbus di atas kompor dengan air sebanyak $240 \mathrm{ml}$ hingga airnya tersisa setengahnya. Setelah itu, dinginkan air rebusan, tuangkan kebotol spray dan hand sanitizer siap digunakan.

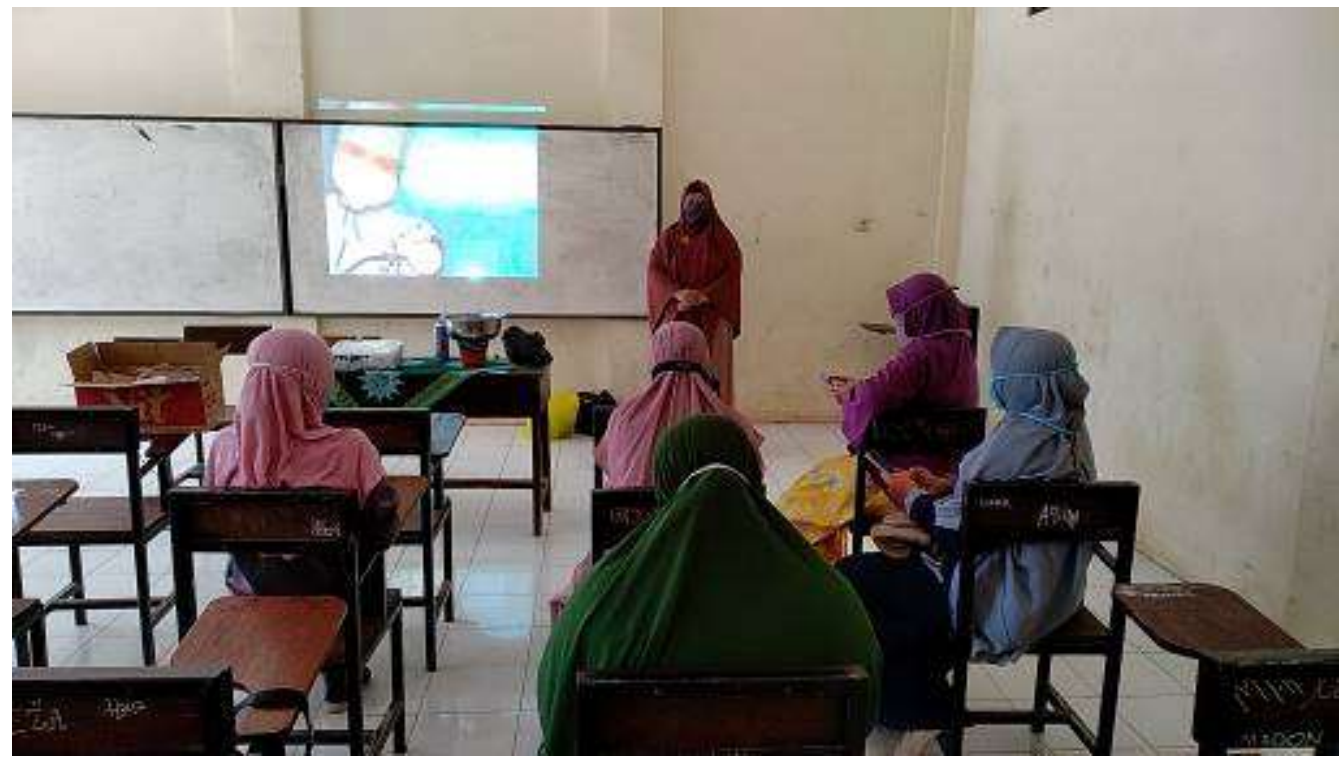

Gambar 2. Ibu Anna, ketua Aisiyah Cileungsi memberikan sambutan 
Setelah pemaparan dan praktek langsung pembuatan hand sanitizer dibuka sesi diskusi, para peserta menyambutnya dengan antusias hal ini dibuktikan dengan banyaknya tanya jawab sehingga diskusi menjadi lebih hidup. Setelah selesai berdiskusi, para agent ini menjadi lebih faham mengenai apa itu covid 19 dan mampu membuat hand sanitizer alami dari daun sirih. Hand sanitizer alami "AC" dan hand sanitizer merk E pabrikan dapat menurunkan angka kuman pada tangan pekerja di Labkesmas Kabupaten Banyumas (Cicaningsih, 2017).

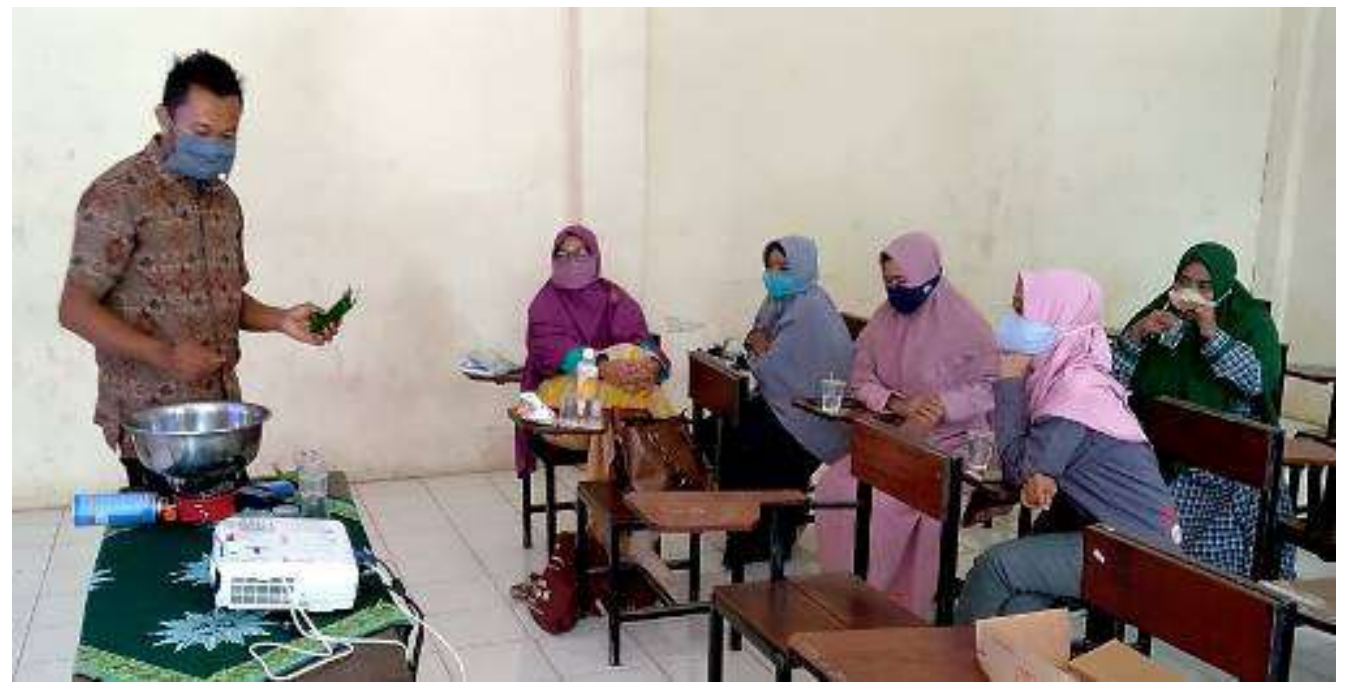

Gambar 3. Pa Devi sedang mempraktekan pembuatan hand sanitizer

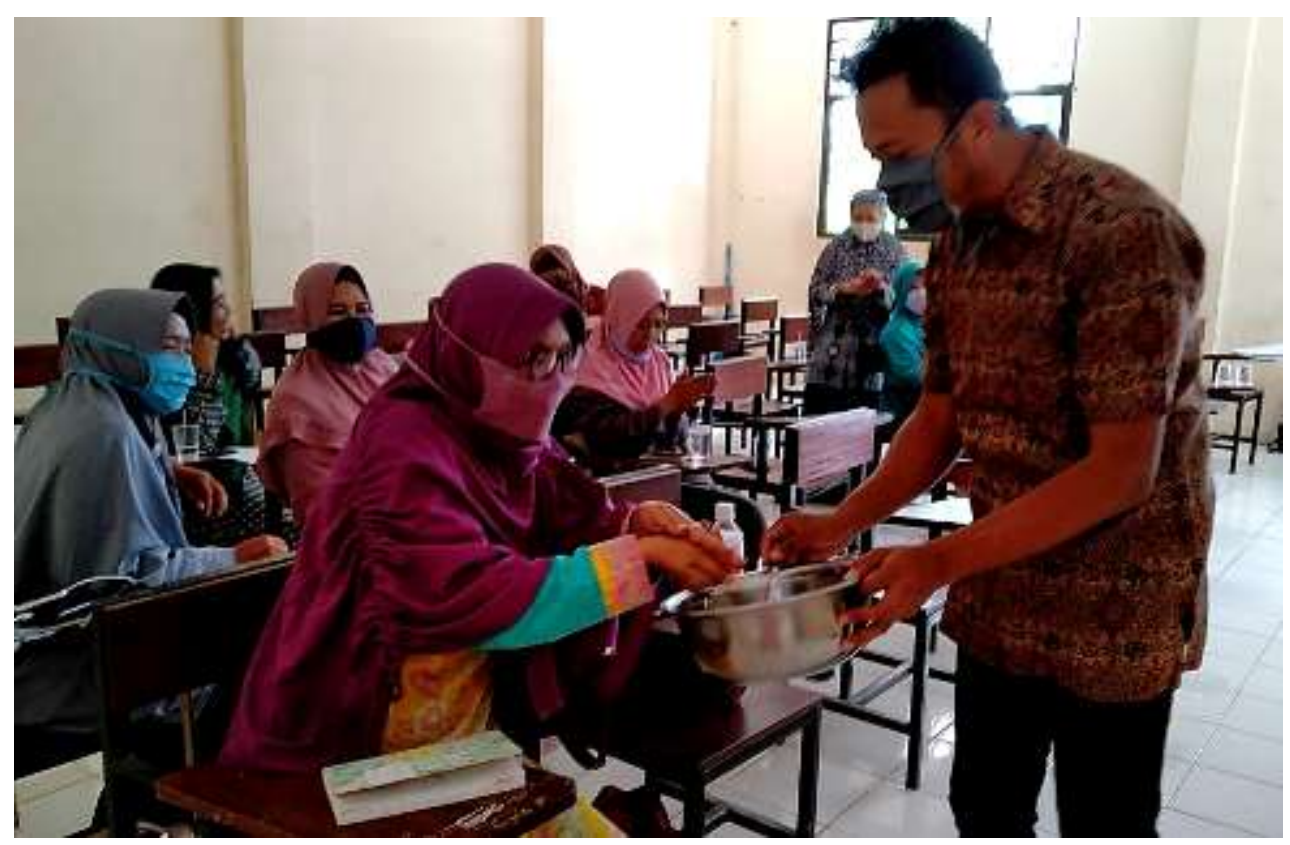

Gambar 4. Aplikasi hand sanitizer alami dari daun sirih

\section{KESIMPULAN}

Peningkatan pengetahuan warga Aisyiyah Muhammadiyah Cileungsi mengenai COVID-19 ini sehingga warga dapat lebih waspada, berhati-hati, dapat menjaga diri dan keluarga dari wabah ini. Warga memiliki keterampilan baru dalam pembuatan hand sanitizer berbahan dasar alami yakni daun sirih yang ada dari lingkungan warga dan pengetahuan tentang manfaat dari hand sanitizer ini. Hand sanitizer ini lebih alami, ramah lingkungan dan lebih aman untuk digunakan. 


\section{UCAPAN TERIMA KASIH}

Penulis mengucapkan terima kasih kepada LPPM UHAMKA yang telah memberi dukungan financial terhadap pengabdian ini dan mitra yang sudah bekerjasama dalam kegiatan pengabdian masyarakat ini.

\section{DAFTAR PUSTAKA}

Cicaningsih, Agustin dan Tri Cahyono. 2017. Komparasi Efektivitas Hand Sanitizer Alami "AC" dan Merk E Terhadap Penurunan Angka Kuman Pada Tangan Pekerja di Lab Kesmas Kabupaten Banyumas Tahun 2017. Keslingmas. Vol 37. No. 3 p. 364-373.

Fatimah, Cut dan Rani, Ardiani. 2018. Pembuatan Hand Sanitizer (Pembersih Tangan Tanpa Air Menggunakan Antiseptik Bahan Alami. Prosiding Seminar Nasional Hasil Pengabdian 2018.

Kamila, Ami. Anzar, Ismail, 2020. Edukasi HIV/AIDS “Gerakan 1000 Remaja Milenial Peduli ODHA (Gerserha) di MA Al- Mukhtariyah Kabupaten Bandung Barat. Dinamisia: Jurnal Pengabdian Kepada Masyarakat.

Lestari, Pramulani Mulya. Ani, Pahriyani. 2018. Pelatihan Pembuatan Hand Sanitizer Perasan Buah Jeruk Nipis Bagi Guru, Siswa Siswi SMA dan SMK Mutiara 17 Agustus Kelurahan Teluk Pucung Bekasi Utara. Jurnal Semar. Vol 6. No. 3. P. 1-6.

Sari, Retno. Dweim Isadiartuti. 2006. Studi Efektivitas Sediaan Gel Antiseptik tangan ekstrak daun sirih (Piper betle Linn.). Majalah Farmasi Indonesia. Vol 17 (4). P. 163-169.

Tjirtosoepomo, Gembong. (2005). Taksonomi Tumbuhan Obat-obatan. Yogyakarta: Gajah Mada University Press

Tim LPPM UHAMKA. (2018). Buku Panduan Pengabdian dan Pemberdayaan Masyarakat.

WHO. 2020. Anjuran mengenai penggunaan masker dalam Konteks COVID-19.

Yarza, Husnin Nahry. Devi, Anugrah., Hilman, Faruq., Rosi Feirina Ritonga. (2019). Pemanfaatan Tanaman Obat di Lingkungan Sekitar Sebagai Tanaman Obat di Muhammadiyah Cileungsi Kabupaten Bogor. Laporan Penelitian.

Zubaidah, Elisabeth Linggiana., dkk., (2008). Ilmu Resep untuk Sekolah Menengah Farmasi/SMK Faramsi (Kelas X). Jakarta: P@B SMF-SMKF 